\title{
Nematode Constraints of Chickpea and Pigeonpea Production in the Semiarid Tropics
}

Chickpea (Cicer arietinum L.) and pigeonpea (Cajanus cajan (L.) Millsp.) are the principal grain legumes (pulses) of subsistence farming systems in the Indian subcontinent and in other regions of the semiarid tropics. These crops are important both in management of soil fertility in the traditional farming systems and as sources of protein in the largely cereal-based diets of the people in the semiarid tropics.

Chickpea is grown in 33 countries, with about 5.6 million $t$ produced on nearly 9.6 million ha (17). Asia accounts for $83 \%$ of the world production of chickpea, a major grain legume in Algeria, Ethiopia, India, Iran, Mexico, Morocco, Myanmar, Pakistan, Spain, Syria, Tanzania, Tunisia, and Turkey. Chickpea is grown as a post-rainy season "winter" crop in the Indian subcontinent. Cultivars adapted to peninsular India mature within 110 days, whereas those adapted to northern India require 170 days. The desi type (small seeds of various colors) is mostly grown in the Indian subcontinent and is consumed as flour, dhal (split pea), and whole seed; desi is also used to some extent as animal feed. The kabuli type (large beige seeds) is grown in the Mediterranean region, the Americas, and, to some extent, the Indian subcontinent; kabuli is usually consumed as whole seed.

Pigeonpea is grown in more than 25 tropical and subtropical countries, with 2.4 million t produced annually on more than 3.4 million ha (28). Reliable yield data are scarce in many regions, however, because pigeonpea is rarely grown as a field crop outside of South Asia and eastern and southern Africa.

Dr. Sharma's address is: International Crops Research Institute for the Semi-Arid Tropics (ICRISAT), Patancheru, Andhra Pradesh 502 324, India

- 1992 The American Phytopathological Society
Pigeonpea is widely adapted to tropical conditions and, with its drought tolerance and deep root system, grows well in semiarid regions. In India, pigeonpea land races and cultivars sown in June or July when the rainy season begins develop into woody shrubs that flower and set pods in the post-rainy season. Cultivars are classified as early (3-5 months), medium (5-6 months), and late (6-9 months) maturing. Approximately $90 \%$ of world pigeonpea production is in the Indian subcontinent, where it is mainly consumed as dhal. In other countries in Asia, Africa, and the Americas, pigeonpea is grown for green or dry seed, usually in low-input systems with low yields.

Many fungi, bacteria, viruses, plantparasitic nematodes, and mycoplasmalike organisms attack chickpea and pigeonpea. Although plant-parasitic nematodes have been associated with chickpea in 17 countries and with pigeonpea in 24 countries (29), only a few diseases caused by nematodes are recognized as important production constraints (Table 1). Yields are reduced when nematodes attack plant roots and Rhizobium nodules (cowpea miscellany group and Cicer group). Although usually not dramatic, yield losses tend to be cumulative, and production is reduced over extended periods (44). Unfortunately, very few chickpea and pigeonpea growers know how to recognize and manage nematode-caused diseases. The need for programs to educate growers about nematode problems and about the inexpensive, environmentally safe, effective controls for nematode diseases is especially acute in the tropics.

\section{Nematode Diseases of Chickpea}

Root knot. Root knot, caused by Meloidogyne spp. is the most serious nematode disease of chickpea (Fig. I). $M$. incognita (Kofoid \& White) Chitwood and $M$. javanica (Treub) Chitwood in the Indian subcontinent and $M$. artiellia Franklin in the Mediterra- nean region are the most damaging species $(8,47)$. $M$. incognita and $M$. javanica are favored by warm weather and become serious problems in regions where winters are mild, as in peninsular India. However, seve re crop damage also occurs in northern India, in the terai (submontane) region of Nepal, and in Pakistan, where minimum air temperature during the winter crop season is less than $15 \mathrm{C}$ for many days. $M$. incognita and $M$. javanica infest various types of soils but cause the most plant damage in sandy and sandy loam soils. In northern India, Upadhyay and Dwivedi (57) reported a $40 \%$ increase in yield when plots infested with $4.6 \mathrm{M}$. incognita juveniles per cubic centimeter of soil were treated with carbofuran. $M$. incognita and $M$. javanica have a very wide host range and in India attack plant species in more than 232 and 141 genera, respectively (22).

Symptoms and disease cycle. Root galls (knots) are the most characteristic symptoms of nematode infection and are easily seen with the unaided eye. Gall size is influenced by soil temperature and susceptibility of the chickpea genotype. Galls produced at $25-30 \mathrm{C}$ are $30-35 \%$ larger than those produced at $15-20 \mathrm{C}$. Galls are formed on the taproot and lateral roots but may be more numerous on the taproot. Aerial parts show no characteristic symptoms, but nematodes reduce plant vigor, delay flowering, and induce early senescence-symptoms that are often confused with decreasing soil fertility and deficiencies of nitrogen, iron, magnesium, sulfur, phosphorus, potassium, and other nutrients (Fig. 2).

Symptom expression and tolerance to nematode population densities vary with genotype. In nematode-infested chickpea fields, patches of stunted plants usually appear earlier in infertile, moisturedeficient sandy soils with low $\mathrm{pH}$. Tolerance limits (number of nematodes a plant can host without measurable damage) vary from 0.2 to 2.0 eggs and/or secondstage juveniles per cubic centimeter of 
soil at the time of sowing.

The life cycle of root-knot nematodes is similar on chickpea and most other hosts. Second-stage juveniles of Meloidogyne spp. are infective. They invade roots, penetrate the cortex, and become established in the vascular cylinder, where they induce formation of the giant cells on which they feed. Galls are initiated within 48 hours after infection but are not essential for nematode growth and development. Juveniles feed and begin to grow slightly longer and much wider, undergoing three molts to become adults. Males are vermiform and females are pyriform. Females deposit 300-1,000 eggs in a gelatinous matrix, and infective second-stage juveniles hatch from the eggs. $M$. javanica and $M$. incognita have a life cycle of approximately 1 month at optimum temperatures of 25-30 C, and many generations are completed in a crop season.

Pathogen interactions. $M$. incognita and $M$. javanica interfere with nitrogenfixation and suppress the formation of Rhizobium nodules in chickpea cultivars JG 62, K 850, and JG 74. Association of these nematodes with Fusarium oxysporum f. sp. ciceri advanced the onset of Fusarium wilt from 31 to 16 days after seedling emergence in chickpea genotypes and increased the disease incidence from 25 to $56 \%$ (27). However, host genotype influences the extent of interactions between nematode species and the wilt fungus. Vascular discoloration after fungus infection does not extend beyond the collar region in wilt-resistant genotypes. Coinfection with $M$. javanica does not modify the reaction of most such genotypes (e.g., ICC 11311, 11313, 12245), but in some (e.g., ICC 11319), discoloration extends beyond the collar region. Also, the nematode moderates wilt resistance in the cultivar ICC 12275.
$M$. javanica modifies the resistance of chickpea cv. Avrodhi to F. oxysporum at Kanpur in northern India (58) but not to race 1 at Patancheru in southern India. Susceptible cultivars die earlier from wilt when coinfected with nematodes.

Root-knot nematodes also interact with other species of Fusarium and with species of Glomus, Rhizoctonia, and Sclerotium. These fungi reduce the population densities of the nematodes $(4,6,7$, $24,26,27,32,55)$.

Management options. Population densities of parasitic nematodes on chickpea are reduced by soil solarization during summer months (51) and by soil application of aldicarb, carbofuran, fenamiphos, and phorate ( $1-4 \mathrm{~kg}$ a.i./ ha) $(10,34)$. Seed treatment with these biocides $(1-6 \%, \mathrm{w} / \mathrm{w})$ is also effective $(18,23)$. More than 250 chickpea genotypes have been reported as resistant to root-knot nematodes in India (43), but later evaluations have not confirmed such resistance. At the International Crops Research Institute for the SemiArid Tropics (ICRISAT), all of 1,000 chickpea genotypes and 35 accessions of wild species of Cicer evaluated for resistance to $M$. javanica were susceptible and the cultivars Bheema, N 31, and N 59 were tolerant. Sesame, mustard, and winter cereals are poor hosts of $M$. javanica and $M$. incognita, and 2- to 3year rotations may be useful for disease management.

Root lesion. Root lesions caused by Pratylenchus spp. are widespread. $P$. thornei Sher \& Allen damages chickpea in India and Syria, and P. brachyurus (Godfrey) Goodey is important in Brazil $(8,47)$. The nematodes penetrate roots and move within the cortical parenchyma. While moving from cell to cell, the nematodes create large cavities and cause necrosis of tissues. Infection is characterized by dark brown to black lesions on the roots (Fig. 3). A population of 0.1 nematode per cubic centimeter of soil significantly reduced plant height, shoot mass, and number of Rhizobium nodules (59), and more than 8.0 nematodes per cubic centimeter of soil reduced seed germination by $34 \%$ and caused a $10 \%$ seedling mortality of chickpea cultivar BG 203 (60). Damage caused by root-lesion nematodes usually is less evident than that caused by rootknot nematodes.

Management options. Information is limited on the management of root-lesion disease of chickpea. Chemicals that control root knot are also effective against Pratylenchus spp. The very wide host range of $P$. thornei limits options for rotations (8). In preliminary tests in central India, chickpea genotypes ICC $11315,11323,12233,12239,12242$, $12245,12253,12269,12270$, and 12275 showed resistance to $P$. thornei (1).

\section{Nematode Diseases of Pigeonpea}

Pearly root. Pearly root of pigeonpea caused by Heterodera cajani Koshy (Fig. 4) exists in the major pigeonpeaproducing states of Andhra Pradesh, Bihar, Gujarat, Haryana, Karnataka, Maharashtra, Punjab, Rajasthan, Tamil Nadu, and Uttar Pradesh in India and in some areas of Egypt. The nematode is widespread in sandy loam soils in northern India and in black-cotton soils (Vertisols) in southern India. Its host range is limited and largely confined to species of the Leguminosae. Of 21 host plant species, only Sesamum indicum (Pedaliaceae) and Phyllanthus maderaspatensis (Euphorbiaceae) are nonlegumes $(20,53)$. Nematode infection reduces foliage production and grain yield (40). At sowing time, population densities of more than 2.0 eggs and juveniles per cubic centimeter of soil may

Table 1. Important nematode-caused diseases of chickpea and pigeonpea

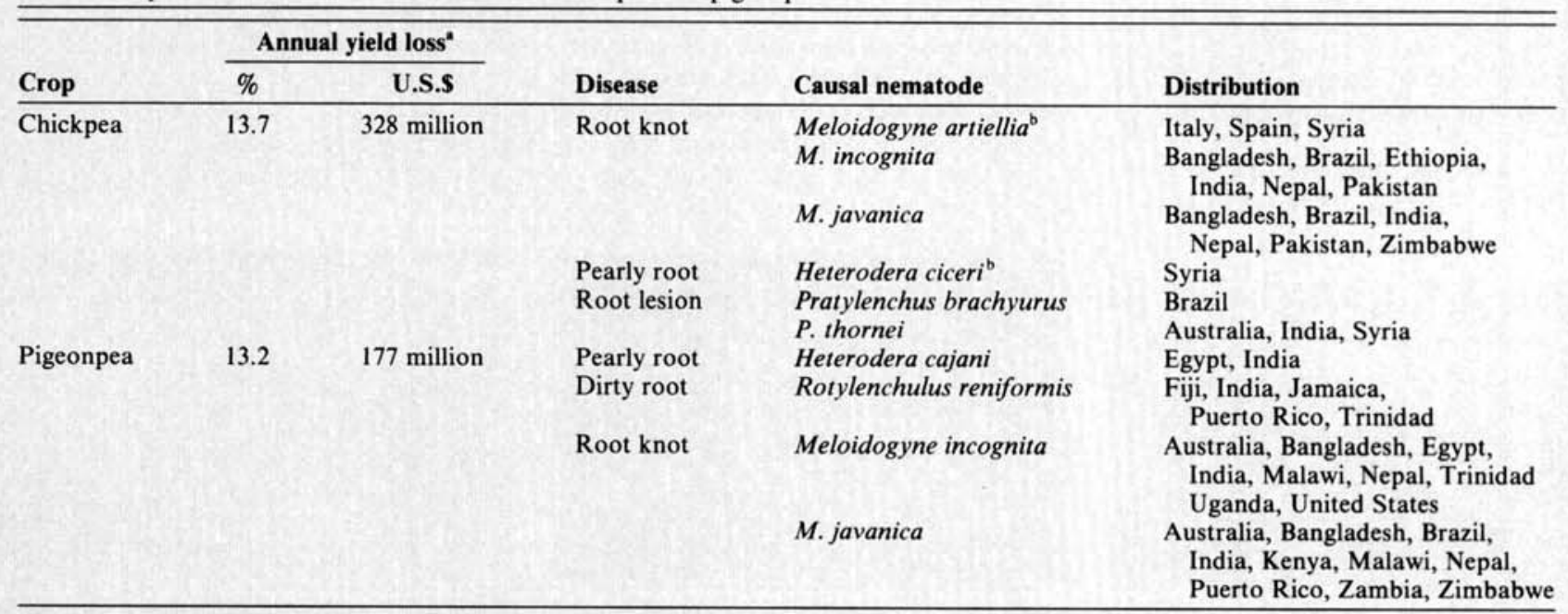

${ }^{3}$ Yield loss estimated on world basis (37); dollar loss calculated with 1989 crop prices.

${ }^{b}$ Not important in the tropics. 


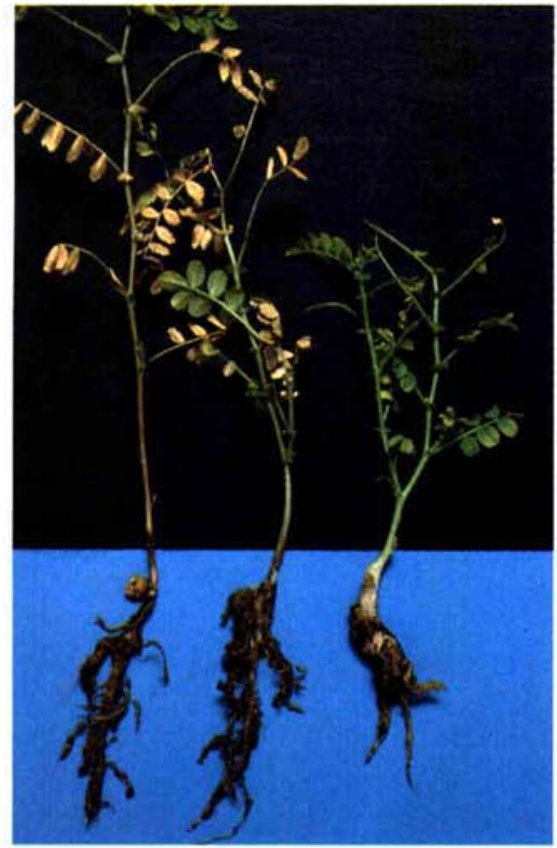

Fig. 1. Chickpea with root knots (galls) caused by Meloidogyne javanica.

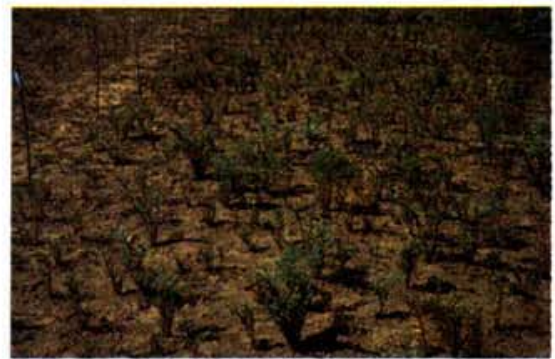

Fig. 2. Low vigor and uneven growth of chickpea planted in sandy soil in Nepal infested with root-knot nematodes.

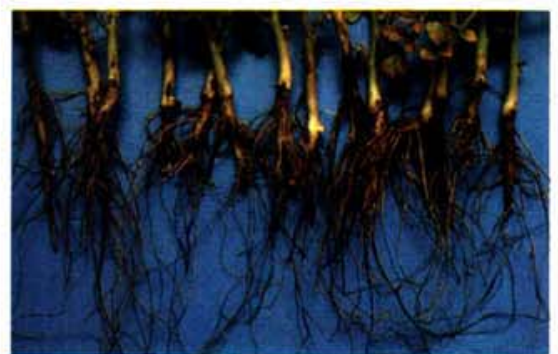

Fig. 3. Chickpea with root-lesion disease caused by Pratylenchus spp.

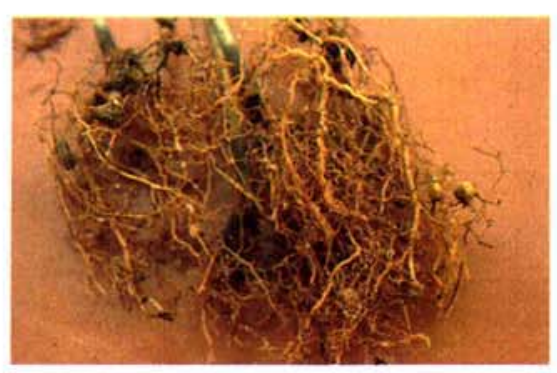

Fig. 4. Pigeonpea with pearly root caused by Heterodera cajani. The small, pearlilike bodies are female nematodes.

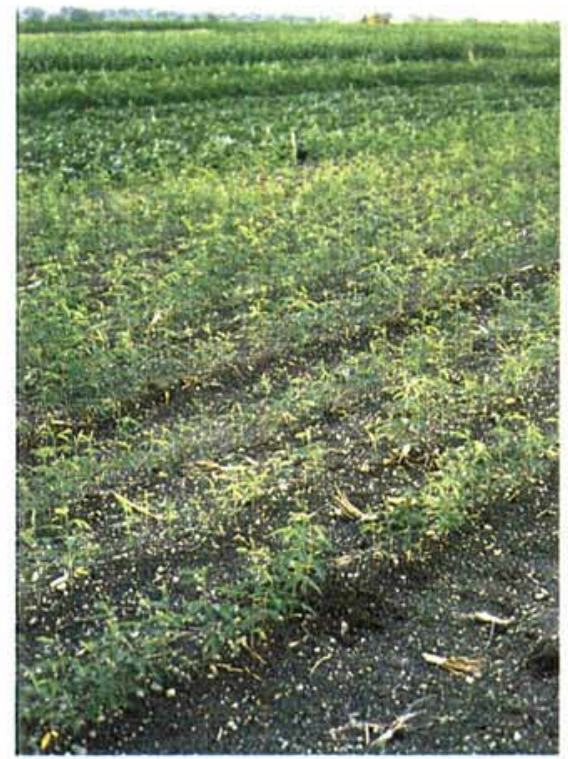

Fig. 5. Sparse, yellow foliage and stunted growth of pigeonpea planted in a field infested with Heterodera cajani.

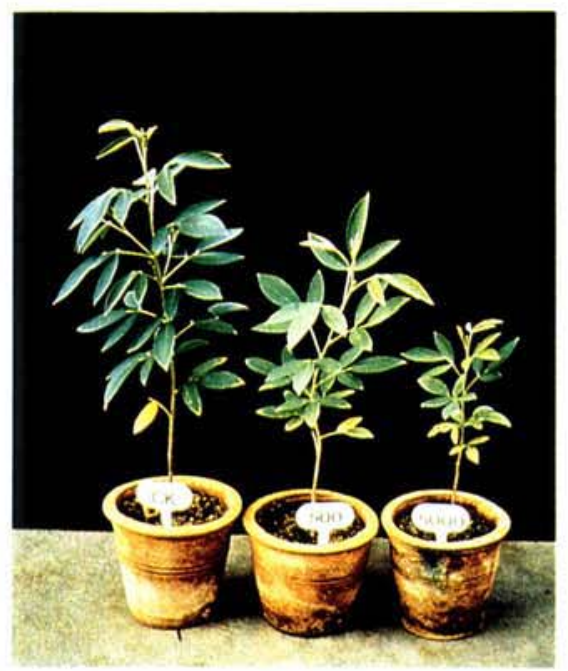

Fig. 6. Pigeonpea genotype ICP 2376 (left) with no Heterodera cajanl added to pot and with (center) 500 and (right) $\mathbf{5 , 0 0 0}$ juveniles added per pot.

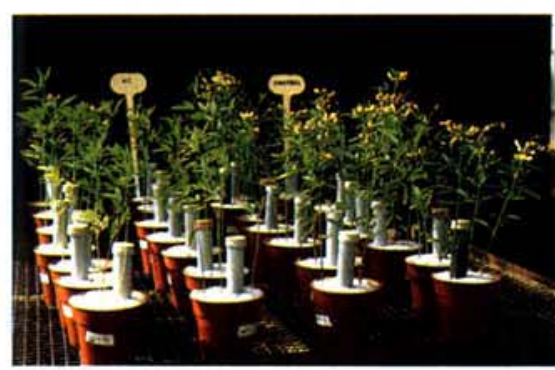

Fig. 7. Flowering and podding of pigeonpea genotype ICPL 87 in soil (two rows at left) infested and (two rows at right) not infested with Heterodera cajanl.

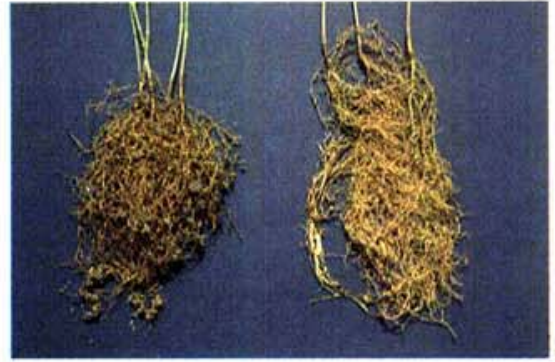

Fig. 8. Pigeonpea (left) with dirty root caused by Rotylenchulus reniformis compared with (right) healthy plant.

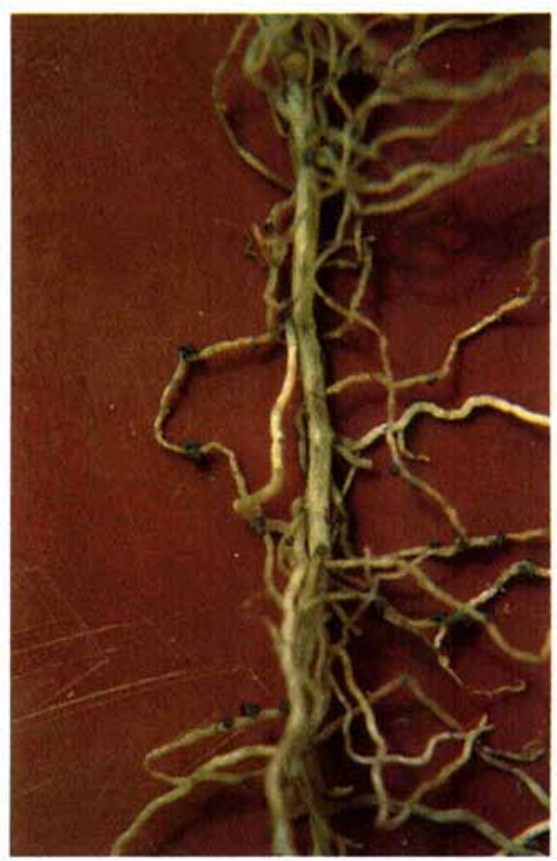

Fig. 9. Egg sacs of Rotylenchulus reniformis on pigeonpea roots stained with trypan blue.
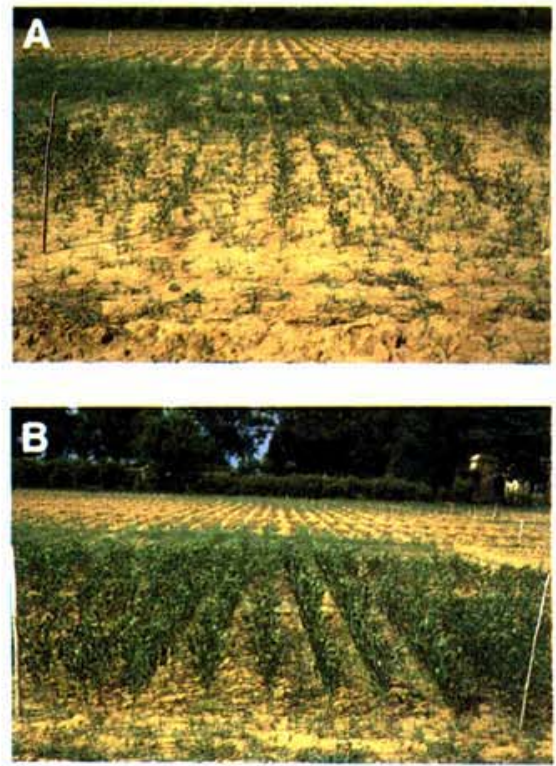

Fig. 10. Growth of pigeonpea in plots infested with Rotylenchulus renlformis: (A) Untreated and (B) treated with carbofuran. 
cause a $30 \%$ reduction in plant biomass and seed yield. Population densities of $H$. cajani reach very high levels on latematuring pigeonpea cultivars, which are greatly affected because the nematode has multiple generations in each crop season (19).

Symptoms and disease cycle. The first symptoms of $\boldsymbol{H}$. cajani infestation are the poor growth and stunted appearance of plants (Figs. 5 and 6), evident 30-45 days after sowing. The roots of 30- to 45-dayold infected seedlings bear many pearly white females of $\boldsymbol{H}$. cajani; the females turn brown as they mature.

The nematode feeds endoparasitically in the stelar region (21). Females enlarge and damage the cortex and epidermis; widespread rupture and discontinuity of xylem vessels ensue. The life cycle is completed within 16 days at $29 \mathrm{C}$, and many generations are completed during the crop season, particularly on latematuring pigeonpea genotypes. Nematode infestation delays flowering and pod formation for more than a week (Fig. 7).

Females of $\boldsymbol{H}$. cajani lay eggs in egg sacs and within the body; the dead female body is referred to as a cyst. Infective second-stage juveniles emerge from egg sacs and cysts at 20-35 C. Emergence of juveniles from cysts is temperaturedependent, with $28 \mathrm{C}$ the optimum; emergence from egg sacs is not as temperature-sensitive. More than $80 \%$ of juveniles emerge from egg sacs, $52 \%$ from white cysts, and $35 \%$ from brown cysts in 15 days at $28 \mathrm{C}$ (53). Few juveniles undergo dormancy in the cyst; in the absence of a host, the nematode can survive for many years in the cyst. In Vertisols, summer fallow (February-June) reduces the number of eggs and juveniles by $18 \%$ at depths of $0-15$ $\mathrm{cm}$ and by $11 \%$ at depths of $15-30 \mathrm{~cm}$ (52).

Pathogen interactions. $H$. cajani enhances the aggressiveness of Fusarium udum in wilt-susceptible pigeonpea (e.g., ICP 2376) but not in wilt-tolerant (e.g., BDN 1) or wilt-resistant (e.g., ICP 8863) genotypes. The fungus is antagonistic to the nematode population, however. Nematode infection suppresses Rhizobium nodulation $(5,11,49)$.

Management options. Application of aldicarb, carbofuran, fensulfothion, and phorate to the soil $(1.5-3.0 \mathrm{~kg}$ a.i./ ha) and to seed $(0.5-2.0 \%)$ reduces population densities of the nematode $(9,16,61)$. Cereals are nonhosts of $H$. cajani. Sharma and Swarup (53) reported that Echinochloa colona, Paspalum scrobiculatum, Setaria italica, and Zea mays are nonhosts. Rotations with commonly grown cultivars of sorghum, pearl millet, cotton, groundnut, castor, maize, and rice for 2-3 years may suppress the deleterious effect of $\boldsymbol{H}$. cajani on pigeonpea. Although host plant resistance in pigeonpea germ plasm has not been explored, accessions of Cajanus scarabaeoides are resistant to $H$. cajani and are easily crossed with pigeonpea (39). At ICRISAT, all of 400 pigeonpea genotypes evaluated for resistance to $H$. cajani were susceptible. Soil solarization reduces numbers of $H$. cajani and enhances yield of pigeonpea (51). Pasteuria penetrans infects $H$. cajani, and infected second-stage juveniles form a loosely woven "sticky swarm" in water (41). The bacterial infection completely disintegrates the internal tissues of developing nematodes, and infected nematodes do not produce eggs. Several other biocontrol agents, including Allomyces anomalus, Catenaria auxiliaris, $C$. vermicola, Nematophthora sp., Olpidium sp., and Pythium sp., reduce numbers of eggs and juveniles in soil (42).

Dirty root. Dirty root of pigeonpea is caused by Rotylenchulus reniformis Linford \& Oliveira. This nematode attacks many crops in 38 countries in subtropical and tropical regions (14), and its widespread distribution endangers pigeonpea wherever the crop is grown. The extensive host range includes fruits, vegetables, legumes, oilseeds, ornamentals, millets, and plantation crops. In Fiji, where pigeonpea is a major subsistence and cash crop, the nematode severely reduces yield (13). The nematode is associated with variable growth of pigeonpea in northern India and on sandy and red soils (Alfisols) in western and southern India. A preplant population density of $1.0 R$. reniformis per cubic centimeter of soil can significantly reduce biomass of susceptible pigeonpea cultivars. Damage thresholds range from 1.0 to 4.0 nematodes per cubic centimeter of soil, depending on soil type and climatic factors $(47,48)$.

Symptoms and disease cycle. Dirty root can be diagnosed by observing $R$. reniformis egg sacs on pigeonpea roots. Infected roots appear dirty because soil particles adhere to the mucilaginous egg sacs (Fig. 8) and are not easily dislodged by shaking the roots. Foliage of nematode-infected plants is light green, and young leaves of many infected genotypes become yellow. As with pearly root, aerial parts show no diagnostic symptoms of nematode attack. Patches of stunted plants indicate nematode infection, and the number of such patches increases under drought stress.

The life cycle of $R$. reniformis on pigeonpea and other hosts is completed within a month. Sedentary females lay eggs in sacs. The first molt occurs within the eggs, and second-stage juveniles hatch. Juveniles can survive in the absence of hosts for more than $\mathbf{3 0 0}$ days without losing infectivity (52). Preadult females are infective and penetrate the epidermal cells intercellularly and intracellularly, causing slight browning and necrosis of surrounding cortical cells as they feed in the phloem. Females begin to enlarge on the ventral side around the vulval region, continue to swell, and become reniform within 5 days after infection. Males do not feed.

Pathogen interactions. $R$. reniformis can feed on and reduce the number of Rhizobium nodules. Interactions between $R$. reniformis and $F$. udum have been observed in India and Fiji (47). Although $F$. udum reduces the population density of the nematode, Fusarium wilt-susceptible genotypes such as ICP 2376 die early when the nematode and the fungus are both present in the soil. Reactions of wilt-tolerant (BDN 1) and wilt-resistant (ICP 8863) genotypes are not modified by nematode parasitism (50).

Management options. Chloris gayana, Crotalaria spp., Tagetes erecta, and $T$. patula are poor hosts of $R$. reniformis (2). Rotations for 2-3 years with rice, maize, or groundnut and solarization may reduce the populations of the nematode. Pigeonpea genotypes with resistance to $R$. reniformis have been reported, but such resistance has not been confirmed $(3,31,56)$. At ICRISAT, all of more than 500 pigeonpea genotypes and 40 accessions of related wild species evaluated for resistance to $R$. reniformis were susceptible when assayed by a simple technique (45) of counting egg sacs stained with $0.25 \%$ trypan blue (Fig. 9). Accessions of Rhynchosia aurea, $R$. minima, and $R$. rothii are resistant to the nematode, and two short-duration pigeonpea genotypes, ICPL 83045 and ICPL 85024, are tolerant. Application of carbofuran $(6 \mathrm{~kg}$ a.i./ha) at the time of sowing in fields infested with abovethreshold levels of $R$. reniformis has increased crop yield by $25 \%$ (Fig. 10).

Root knot. $M$. incognita, $M$. javanica, $M$. arenaria (Neal) Chitwood, M. hapla Chitwood, and $M$. acronea Coetzee attack pigeonpea (29). The first two species are widespread in pigeonpeagrowing regions and thus are more important than the others. Pigeonpeas are highly susceptible to $M$. arenaria but not to M. hapla (38). M. acronea is reported only in Malawi, but there is little information on its pathogenicity. Susceptibility may increase when $M$. javanica and $M$. incognita feed together on pigeonpea (Table 2). Some resistant genotypes (ICP 11289, 11299, 8863, and 8860 ) are moderately to heavily galled when both species are present in the soil $(30,54)$.

Symptoms and disease cycle. Nematode infection stunts susceptible pigeonpea genotypes, and roots are moderately to severely galled. When the galls are very small, nematode infection can be verified by examination of roots for egg sacs. Considerable pathogenic variation occurs in populations of $M$. incognita and $M$. javanica on pigeonpea. Some populations in India, Nepal, and Malawi do not induce galls on roots of pigeonpea 
but do produce many egg sacs. Many genotypes on which only egg sacs are produced apparently are not stunted by nematode infection. The disease cycle is similar to that on chickpea.

Pathogen interactions. The nematode species increase the severity of Fusarium wilt (36). M. incognita and $M$. javanica occurring with $F$. udum moderate wilt resistance in the cultivar ICP 8863 (50).

Management options. Resistance to Meloidogyne spp. is available in pigeonpea germ plasm. Among more than 200 genotypes evaluated at ICRISAT for resistance to $M$. javanica, only 13 were highly susceptible. Of the resistant genotypes, ICP 11289, 11299, and ICPL 151 are very promising. ICP 11289 and 11299 have resistance to nematode populations in India, Malawi, and the United States, and ICPL 151 is an earlymaturing cultivar. Cereals are poor hosts of $M$. incognita and $M$. javanica. Rotations with sorghum, pearl millet, Setaria spp., maize, rice, and sesame can reduce the nematode population densities in $2-3$ years. A pigeonpea/wheat cropping system also suppresses the nematode population (47). Seed treatment with $2.0 \%$ carbofuran and benfuracarb is effective (25).

\section{Difficulties and Future Needs}

Considerable progress has been made in identification of nematode-caused diseases and assessment of their damage potential. Future attention should focus on identification of cost-effective and practical management tactics for the most important diseases. The greatest obstacle to effective management is the lack of recognition that nematodes seriously limit crop yields. An urgent need is to educate growers that nematode problems exist and to train farmers and extension workers to detect, diagnose, and control these problems on chickpea and pigeonpea. Availability of trained personnel in the tropics is crucial for completion of this daunting task.

Farmers in the semiarid tropics traditionally manage important pests and diseases with cultural control. Chemical control is rarely an instrument of pest and disease management in subsistence crops. For example, Helicoverpa armigera is a highly destructive foliar insect pest of pigeonpea, but surveys of 10 states of India revealed that only $6 \%$ of the fields were treated with pesticides to control this pest (15). Several expensive pesticides have been tested for control of nematode diseases, but farmers are not expected to use them.

Any nematode management option must be compatible with low-input crop production strategies. Use of solar heat for nematode control is environmentally safe and effective, and coupling solarization with other control measures, such as application of neem cake and other soil amendments, may give long-lasting control of nematode-caused diseases. This management option may be useful in regions where multiple pests and diseases must be controlled, but the cost of the polyethylene sheet required for solarization may keep it beyond reach of resource-poor farmers in developing countries. Use of nematode-resistant cultivars is practical, and useful sources of resistance are available for root-knot nematodes. These promising sources of resistance should be tested extensively and utilized in breeding programs. Techniques for evaluation of resistance should be standardized, and plant breeders should be involved from an early stage in this research. At ICRISAT, screening techniques for evaluating pigeonpea genotypes for resistance and tolerance to $H$. cajani, $R$. reniformis, and $M$. javanica and chickpea genotypes for resistance to $M$. javanica have been standardized $(45,46)$. We need to search for promising sources of resistance and tolerance to nematode diseases so that durable disease-resistant chickpeas and pigeonpeas can be identified.

Cropping systems, rotations, and intensity affect severity of nematode problems. Research at ICRISAT has shown that population densities of nematodes parasitic to pigeonpea in peninsular India can be reduced by removing plant hosts of the nematodes for extended periods. However, weed hosts enable nematode reproduction in the absence of cultivated plant hosts. Although an uncommon practice in pigeonpea and chickpea production, weed control is an essential part of crop rotation for successful management of nematode diseases.

Rotations that include a fallow period are slowly vanishing in parts of the tropics with explosive population growth and declining land productivity. Tropical agriculture needs adequate nematode control with minimum environmental disturbance and little capital input. The objective should be to reduce nematodecaused losses rather than to kill nematodes. A population planning program may permit nematodes to subsist on chickpea and pigeonpea but not in damaging proportions. Research and extension nematologists should provide technology for improved management of nematode diseases and innovative education of farmers. This will benefit the science of nematology and farmers in developed countries as well as resource-poor farmers in the semiarid tropics.

\section{Literature Cited}

1. Anonymous. 1987. Annual report. Pages 29-31 in: All India Coordinated Research Project on Plant Parasitic Nematodes with Integrated Approach for Their Control. Jabalpur, Madhya Pradesh, Department of Plant Pathology.

2. Casewell, E. P., DeFrank, J., Apt, W. J., and Teng, C. S. 1991. Influence of nonhost plants on population decline of Rotylenchulus reniformis. J. Nematol. 23:91-98.

3. Chavda, J. C., Patel, B. A., and Patel, D. J. 1988. Screening of pigeonpea lines to Rotylenchulus reniformis. Int. Nematol. Network Newsl. 5:28-29.

4. Diedericks, C. 1987. Interaction between five endomycorrhizal fungi and the rootknot nematode Meloidogyne javanica on chickpea under tropical conditions. Trop. Agric. 64:353-355.

5. Edward, J. C., and Singh, K. P. 1979. Interaction between Heterodera cajani and Fusarium udum on pigeonpea. Allahabad Farmer 50:23-24.

6. Goel, S. R., and Gupta, D. C. 1986. Interactions of Meloidogyne javanica and Fusarium oxysporum f. sp. ciceri on chickpea. Indian Phytopathol. 39:112114.

7. Goel, S. R., and Gupta, D. C. 1986. Interaction of Meloidogyne javanica and Rhizoctonia bataticola on chickpea (Cicer arietinum L.). Indian J. Nematol 16:133134.

8. Greco, N., and Sharma, S. B. 1990. Progress and problems in the management of nematode diseases. Pages 135137 in: Chickpea in the Nineties. Proc. Int. Workshop Chickpea Improv. 2nd.

9. Gunasekaran, C. R., Muthukrishnan, T. S., and Rajendran, G. 1976. Evaluation of chemicals for controlling pigeonpea cyst nematode, Heterodera cajani in red gram. Madras Agric. J. 63:382-383.

10. Gupta, D. C., and Kaliram. 1981. Studies on the control of Meloidogyne javanica infecting chickpea in different types of soil. Indian J. Nematol. 11:79-80.

11. Hasan, A. 1984. Synergism between Heterodera cajani and Fusarium udum attacking Cajanus cajan. Nematol. Mediterr. 12:159-162.

12. Hasan, A., and Khan, A. M. 1983. Resistance of pigeonpea cultivars to rootknot nematode, Meloidogyne incognita. Int. Pigeonpea Newsl. 2:56.

13. Heinlein, M., and Black, I. D. 1983. The use of fallow, planting techniques and nematicide application for control of
No. of genotypes

\begin{tabular}{lcc} 
Meloidogyne species & screened/no. resistant & References \\
\hline$M$. incognita & $163 / 146$ & $12,33,38$ \\
$M$. javanica & $47 / 42$ & 35,38 \\
$M$. incognita $+M$. javanica & $91 / 13$ & 30,54 \\
$M$. arenaria & $47 / 2$ & 35 \\
Race 1 & $47 / 21$ & 35 \\
Race 2 &
\end{tabular}


Rotylenchulus reniformis in pigeonpea. Fiji Agric. J. 45:35-42.

14. Holdeman, Q. L., Cordas, D., Watson, T., Matsumoto, R., and Siddiqi, I. 1977. Fact finding study on the reniform nematode, Rotylenchulus reniformis. State of California Department of Food and Agriculture.

15. ICRISAT. 1981. Annual report 1979/80. Patancheru, A.P., India.

16. Jaiswal, B. K., Nath, R. P., Haider, M. G., and Pathak, K. N. 1987. Efficacy of some pesticides on Meloidogyne javanica and Rotylenchulus reniformis infesting pigeonpea. Indian J. Nematol. 17:60-61.

17. Jodha, N. S., and Subba Rao, K. V. 1987. Chickpea: World importance and distribution. Pages 1-10 in: Chickpea. M. C. Saxena and K. B. Singh, eds. Commonwealth Agricultural Bureaux, U.K.

18. Kaushik, H. D., and Bajaj, H. K. 1981. Control of root-knot nematode Meloidogyne javanica infesting mung bean and gram by seed treatment. Haryana Agric. Univ. J. Res. 11:106-108.

19. Koshy, P. K., and Swarup, G. 1971. On the number of generations of Heterodera cajani, the pigeonpea cyst nematode, in a year. Indian J. Nematol. 1:88-90.

20. Koshy, P. K., and Swarup, G. 1972. Susceptibility of plants to pigeonpea cyst nematode, Heterodera cajani. Indian $\mathbf{J}$. Nematol. 2:1-6.

21. Koshy, P. K., and Swarup, G. 1979. Histopathology of pigeonpea roots infested with Heterodera cajani Koshy, 1967. Indian J. Nematol. 9:178-179.

22. Krishnappa, K. 1985. Nematology in developing countries: India-IMP Region III. Pages 379-398 in: An Advanced Treatise on Meloidogyne. Vol. 1. Biology and Control. J. N. Sasser and C. C. Carter, eds. North Carolina State University, Raleigh.

23. Mani, A., and Sethi, C. L. 1984. Influence of seed treatment on seedling emergence of chickpea in presence of Meloidogyne incognita, Fusarium oxysporum $\mathrm{f}$. $\mathrm{sp}$ ciceri and $F$. solani. Indian J. Nematol. 14:68-69.

24. Mani, A., and Sethi, C. L. 1987. Interactions of root-knot nematode, Meloidogyne incognita with Fusarium oxysporum f. sp. ciceri and $F$. solani on chickpea. Indian J. Nematol. 17:1-6.

25. Mishra, S. D. 1986. Control of root-knot nematodes Meloidogyne incognita infesting pigeonpea by nematicidal seed treatment. Pages 34-36 in: Proc. Natl. Symp. New Dimensions Parasitol.

26. Mukhtar, J., and Khan, A. A. 1989. Disease complex in chickpea involving Meloidogyne incognita with Fusarium oxysporum f. sp. ciceri and $F$. solani on chickpea. Indian J. Nematol. 17:1-6.

27. Nath, R., and Dwivedi, R. P. 1981. Effect of root-knot nematode on development of gram caused by Fusarium oxysporum f. sp. ciceri and root rot by Rhizoctonia sp. Indian J. Mycol. Plant Pathol. 11:4649.

28. Nene, Y. L., and Sheila, V. K. 1990. Pigeonpea: Geography and importance. Pages 1-14 in: The Pigeonpea. Y. L. Nene, S. D. Hall, and V. K. Sheila, eds. Commonwealth Agricultural Bureaux, U.K.

29. Nene, Y. L., Sheila, V. K., and Sharma, S. B. 1989. A world list of chickpea (Cicer arietinum L.) and pigeonpea (Cajanus cajan (L.) Millsp.) pathogens. Legumes pathology progress report 7. ICRISAT, Patancheru, A. P., India. 23 pp.

30. Patel, B. A., Chavda, J. C., Patel, S. T., and Patel, D. J. 1987. Susceptibility of some pigeonpea lines to root-knot nematodes (Meloidogyne incognita and M. javanica). Int. Pigeonpea Newsl. 6:5557.

31. Patel, B. A., Chavda, J. C., Patel, S. T., and Patel, D. J. 1987. Reaction of some pigeonpea lines to reniform nematode, Rotylenchulus reniformis. Int. Pigeonpea Newsl. 6:57-58.

32. Patel. H. R., Thakar, N. A., Patel, B. K., and Patel, C. C. 1987. Interaction between Meloidogyne incognita and Fusarium oxysporum f. sp. ciceri on chickpea variety Chaffa. Indian J. Nematol. 17:124.

33. Ravichandra, N. G., Krishnappa, K., Anilkumar, T. B., and Saifulla, M. 1988. Reaction of pigeonpea lines to the rootknot nematode (Meloidogyne incognita). Int. Pigeonpea Newsl. 7:31-32.

34. Reddy, D. D. R. 1975. Pathogenicity and control of root-knot nematodes (Meloidogyne spp.) infecting chickpea. Mysore J. Agric. Sci. 9:434-439.

35. Saka, V. W. 1990. Evaluation of common bean (Phaseolus vulgaris), groundnut (Arachis hypogaea) and pigeonpea (Cajanus cajan) for resistance to rootknot nematodes (Meloidogyne spp.). Field Crop Res. 23:39-44.

36. Salam, M. A., and Khan, M. W. 1986. Reaction of some cultivars of pigeonpea against Fusarium udum and Meloidogyne javanica. Int. Nematol. Network Newsl. 3:16-17.

37. Sasser, J. N. 1987. A perspective on nematode problems worldwide. Pages 1-12 in: Proc. Nematodes Parasit. Cereals Legumes Temperate Semi-arid Reg. M. C. Saxena, R. A. Sikora, and J. P. Srivastava, eds. International Center for Agricultural Research in the Dry Areas, Aleppo, Syria.

38. Sasser, J. N., and Hartman, K. M. 1985. Evaluation of some pigeonpea lines for resistance to the root-knot nematodes, Meloidogyne spp. Int. Pigeopnea Newsl. 4:44-45.

39. Saxena, K. B., Singh, L., Reddy, M. V., Singh, U., Lateef, S. S., Sharma, S. B., and Remanandan, P. 1990. Intra species variation in Atylosia scarabaeoides (L.) Benth., a wild relative of pigeonpea (Cajanus cajan (L.) Millsp.). Euphytica 49:185-191.

40. Saxena, R., and Reddy, D. D. R. 1987. Crop losses in pigeonpea and mungbean by pigeonpea cyst nematode, Heterodera cajani. Indian J. Nematol. 17:91-94.

41. Sharma, R., and Sharma, S. B. 1989. Sticky swarm disease of Heterodera cajani and Meloidogyne javanica caused by Pasteuria penetrans. Int. Pigeonpea Newsl. 10:26-27.

42. Sharma, R., and Swarup, G. 1988. Pathology of Cyst Nematodes. Malhotra Publishing House, New Delhi, India. 88 pp.

43. Sharma, S. B. 1987. Nematology. Progress report 1. ICRISAT, Patancheru, A.P., India. 33 pp.

44. Sharma, S. B. 1988. Nematology in the year 2000 A.D. as I see it in relation to dryland farming. Pages 44-52 in: Proc. Nematol. 2000 A.D. Indian Agricultural Research Institute, New Delhi.

45. Sharma, S. B., and Ashokkumar, P. 1991. A screening technique to evaluate 
pigeonpea for resistance to Rotylenchulus reniformis. Ann. Appl. Biol. 119:323-330.

46. Sharma, S. B., Ashokkumar, P., and McDonald, D. 1991. A greenhouse technique to screen pigeonpea for resistance to Heterodera cajani. Ann. Appl. Biol. 118:351-356.

47. Sharma, S. B., and McDonald, D. 1990. Global status of nematode problems of groundnut, pigeonpea, chickpea, sorghum, and pearl millet. Crop Prot. 9:453458.

48. Sharma, S. B., and Nene, Y. L. 1988. Effect of Heterodera cajani, Rotylenchulus reniformis and Hoplolaimus seinhorsti on pigeonpea biomass. Indian J. Nematol. 18:273-278.

49. Sharma, S. B., and Nene, Y. L. 1989. Interrelationship between Heterodera cajani and Fusarium udum in pigeonpea. Nematropica 19:21-28.

50. Sharma, S. B., and Nene, Y. L. 1990. Effect of Fusarium udum-alone and in combination with Rotylenchulus reniformis or Meloidogyne spp.-on wilt incidence, pigeonpea growth, and nematode reproduction. Int. J. Trop. Plant Dis. 8:95-101.

51. Sharma, S. B., and Nene, Y. L. 1990. Effect of soil solarization on nematodes parasitic to chickpea and pigeonpea. $\mathbf{J}$. Nematol. 22S:658-664.

52. Sharma, S. B., and Nene, Y. L. Spatial and temporal distribution of plantparasitic nematodes on pigeonpea in alfisols and vertisols. Nematropica. (In press.)

53. Sharma, S. B., and Swarup, G. 1984. Cyst-Forming Nematodes of India. Cosmo Publications, New Delhi. $152 \mathrm{pp}$.

54. Thakar, N. A., and Patel, D. J. 1985. Susceptibility of pigeonpea varieties to root-knot nematodes, Meloidogyne incognita and $M$. javanica. Int. Pigeonpea Newsl. 4:43-44.

55. Thakar, N. A., Patel, H. R., Patel, B. K., and Patel, C. C. 1986. Breaking of resistance to Fusarium wilt in resistant chickpea by root-knot nematode. Madras Agric. J. 73:410-411.
56. Thakar, N. A., and Yadav, B. S. 1985. Screening pigeonpea for their resistance to reniform nematode. Int. Pigeonpea Newsl. 4:42-43.

57. Upadhyay, K. D., and Dwivedi, K. 1987. Analysis of crop losses in pea and gram due to Meloidogyne incognita. Int. Nematol. Network Newsl. 4:6-7.

58. Upadhyay, K. D., and Dwivedi, K. 1987. Root-knot nematode, Meloidogyne javanica breaks wilt resistance in chickpea variety Avrodhi. Curr. Sci. 56:915-916.

59. Walia, R. K., and Seshadri, A. R. 1985. Pathogenicity of the root-lesion nematode, Pratylenchus thornei, on chickpea Int. Chickpea Newsl. 12:31.

60. Walia, R. K., and Seshadri, A. R. 1985. Chemical control of Pratylenchus thornei on chickpea through seed treatment. Int. Chickpea Newsl. 13:32-34.

61. Zaki, F. A., and Bhatti, D. S. 1986. Control of pigeonpea cyst nematode, Heterodera cajani Koshy, by chemical seed treatment. Indian J. Nematol. 16:106-107.

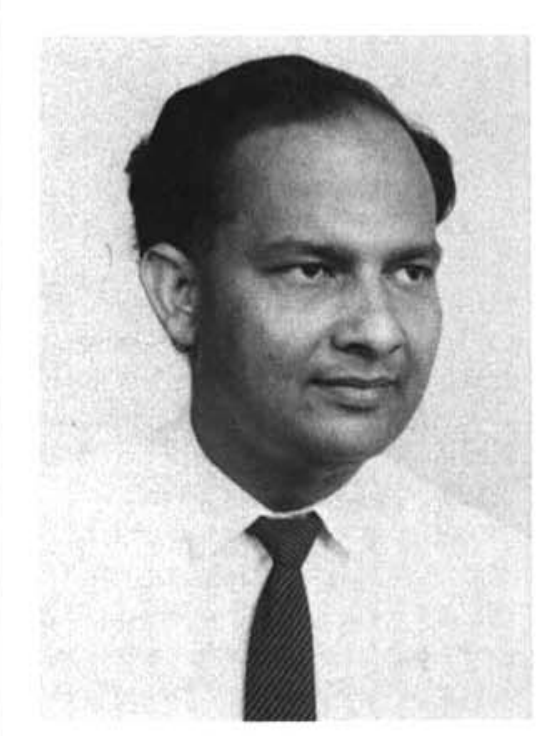

S. B. Sharma

$\mathrm{Dr}$. Sharma is a plant nematologist with ICRISAT and is working on management of nematode-caused diseases of grain legumes in the semiarid tropics. His research is centered mainly on determining the role of nematodes in reducing crop productivity; on identifying host-plant resistance to important nematodes of pigeonpea, chickpea, and groundnut; and on basing management of nematode diseases on cropping systems. He received his M.Sc. and Ph.D. degrees from the Indian Agricultural Research Institute in New Delhi. He has traveled extensively in parts of Asia and Africa in connection with research on nematodes associated with grain legumes and has published more than 60 papers as well as the book Cyst Forming Nematodes of India. Recently he received the Pran Vohra Award from the Indian Science Congress Association for significant research work in the field of agricultural sciences.

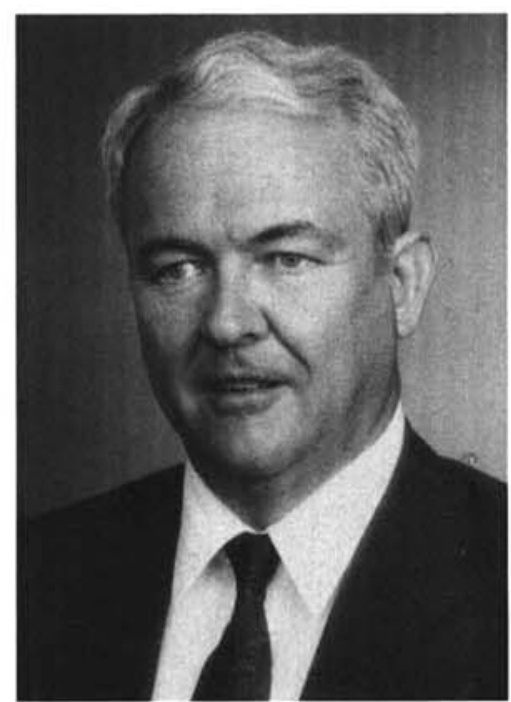

D. H. Smith

Dr. Smith received his Ph.D. degree in plant pathology from Pennsylvania State University in 1966. He was a Kettering Foundation postdoctoral fellow at Albion College, Albion. Michigan, from 1966 to 1967 and an assistant professor of plant pathology at the Georgia Agricultural Experiment Station in Griffin from 1967 to 1973. $\mathrm{He}$ then went to the Texas Agricultural Experiment Station in Yoakum, where he was an associate professor of plant pathology from 1973 to 1982 and professor from 1982 to 1990 . Dr. Smith is currently principal plant pathologist in the Legumes Program at ICRISAT and is involved in research on diseases of groundnut (peanut), pigeonpea, and chickpea. $\mathrm{He}$ is a former executive secretary-treasurer and president of the American Peanut Research and Education Society and currently is a fellow of the society, which honored him with the Coyt T. Wilson Award for service.

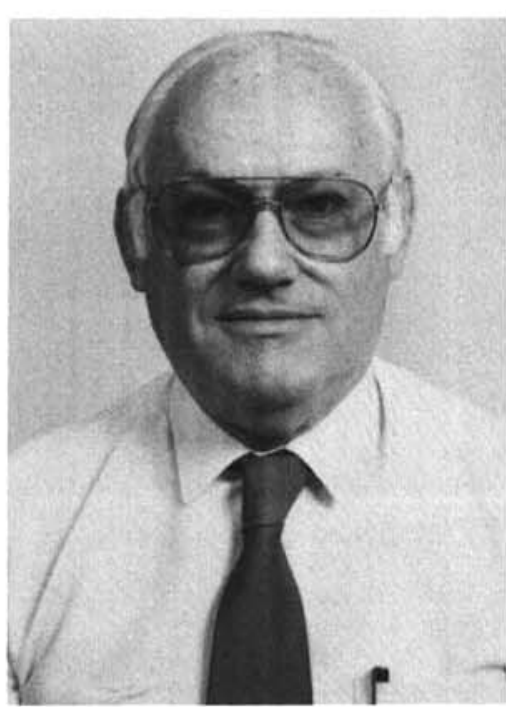

\section{McDonald}

$\mathrm{Dr}$. McDonald is director of the ICRISAT Legumes Program and is interested principally in international cooperative research on legume crops and diseases of groundnut. $\mathrm{He}$ received his Ph.D. degree in botany from Ahmadu Bello University, Nigeria, in 1968. He was a plant pathologist at that university from 1955 to 1974 , then professor and head of the Department of Crop Protection from 1974 to 1978 , when he joined ICRISAT as principal groundnut pathologist. At ICRISAT he has been involved in various aspects of disease management, particularly identification and utilization of disease resistance, and in multilocation trials and disease nurseries in the Americas, Africa, Asia, and Australia. Dr. McDonald has published more than 150 papers, including seven chapters in books and six information bulletins. 